\title{
Hematopoietic Cell Transplant Recipient
}

National Cancer Institute

\section{Source}

National Cancer Institute. Hematopoietic Cell Transplant Recipient. NCI Thesaurus. Code C126836.

An individual receiving a hematopoietic cell transplant. 